\title{
Valget i Kenya: Hvad gik galt?
}

Jørgen Elklit

\section{Afslutningen på det seneste valg i Kenya kulmine- rede i et overraskende og deprimerende volds- orgie. Mange mente, at volden især blev udløst af en kombination af åbenlys forvirring omkring op- gørelsen af præsidentvalget og bevidst snyd. Men som så ofte før var virkeligheden betydelig mere kompliceret}

Forberedelsen, gennemførelsen, optællingen og annonceringen af resultatet af præsidentvalget i Kenya i december 2007 var i de fleste henseender en skandale, men alligevel er det kun de allersidste faser af processen, der kom til at spille en rolle for vælgernes - og omverdenens bedømmelse af valget. Dét blev afgørende for udviklingen i en af de mest forunderlige valgprocesser, der længe er set i Afrika.

Holger Bernt Hansen har allerede for et års tid siden givet sin fremstilling af, hvad der var vigtigt for at forstå udviklingen omkring valget $\mathrm{i}$ Kenya i december 2007. Artiklen i Udenrigs (2.2008) giver et sikkert og dækkende billede af den opfattelse, man på det tidspunkt måtte have, ligesom den også illustrativt og inte- ressevækkende diskuterer, i hvilken grad man kan drage paralleller mellem valget i Kenya og præsidentvalget (i to runder) i Zimbabwe i foråret 2008.

Problemet er bare, at dengang havde ingen rigtigt fattet, hvad det var, der var gået galt ved valget i Kenya i december 2007. Man registrerede udbredt utilfredshed med opgørelsen af valget og annonceringen af resultatet, men hvorfor førte det til omfattende optøjer - mange steder nærmest i form af såkaldt ethnic cleansing-med mindst 1.200 dræbte og mange, mange flere tilskadekomne, voldtagne og på anden vis forulempede? Hertil kom, at urolighederne og frygten for, hvad der ville kunne ske, fik mange til at søge til mere trygge områder, dvs. områder, 
der ikke var dominerede af landsmænd fra fjendtlig stemte stammer. Et sted mellem 400.000 og 500.000 kenyanerne endte af den grund med at leve som internt fordrevne personer.

Der er altså et behov for en mere dækkende analyse af begivenhedsforløbet og dets årsager, end man hidtil har set. Det er denne artikels ambition at imødekomme dette behov, som efter min opfattelse forudsætter en kronologisk-systematisk tilgang til emnet.

\section{Forventningerne til valget}

Det er hensigtsmæssigt at sondre mellem forventningerne til, hvorledes valget rent administrativt og organisatorisk ville blive afviklet, og forventningerne til, hvorledes resultatet ville blive. Af hensyn til den sproglige enkelhed, vil der i øvrigt i artiklen generelt blive henvist til 'valget', selv om der - som det også tidligere havde været tilfældet i Kenya - faktisk skulle afvikles tre valg samtidigt: Præsidentvalg, parlamentsvalg og lokalvalg. Det øger naturligvis presset på valgadministrationen at skulle afvikle tre valg samtidigt, men det er man altså vant til i Kenya, som man også er det i en række andre afrikanske lande.

Forventningerne til kvaliteten af den administrative og organisatoriske afvikling af valgene var på forhånd ganske høje. Det hang sammen med, at formanden for Kenyas
Valgkommission (ECK), Samuel Kivuitu, i 2006 var blevet genudnævnt til sin post.

Der havde - som vanligt - været kritik af udnævnelsen af en række nye medlemmer af den 22 mand store valgkommission kort tid inden, der skulle være valg, men kritikken tog af, da det blev klart, at Kivuitu igen ville komme til at sidde for bordenden i ECK. Han havde nemlig haft det overordnede ansvar for afviklingen af valgene i 2001 (som ikke havde givet anledning til særlige problemer) og folkeafstemningen i 2005 (hvor der heller ikke var meget at komme efter). Derfor var der såvel blandt kenyanske vælgere og kommentatorer som i donorkredse klare forventninger om, at med Kivuitu ved roret ville valgets afvikling ikke komme til at give problemer.

Et konkret udslag af disse positive forventninger var en betydelig interesse blandt donorerne $i$ at støtte valgets afvikling. Mange mente, at Kenya generelt var inde i en god og positiv udvikling ( $\varnothing$ konomisk, politisk, administrativt, om end der fortsat var et højt korruptionsniveau), og derfor kunne det være en god idé at støtte denne generelt positive udvikling ved at bidrage til, at også det kommende valg fik et godt og forhåbentlig helt uproblematisk forløb.

Det kunne være godt for Kenya, men det kunne også sende nogle ønskværdige signaler til andre lande 
i regionen og i Afrika i det hele taget. Så derfor blev der etableret et solidt og bredspektret donorsamarbejde om at støtte valgprocessen, med eget sekretariat, forankring hos UNDP og med USA i den ledende rolle. Men alle seriøse donorer i Kenya (herunder naturligvis også Danmark) var med; og projektet havde et budget på ikke mindre end godt 12 mio. USD.

Forventningerne til valgets udfald var også ret klare hos mange iagttagere og politiske aktører. Ved folkeafstemningen i 2005 havde modstanderne af regeringens og præsident Kibakis forfatningsforslag vundet. Symbolet for 'nej' på stemmesedlen havde været en appelsin, og derfor fortsatte man med at tale om 'the orange movement', tydeligvis også inspireret af den ukrainske oppositions sejr over en upopulær regering i 2004. Argumentationen var simpelthen, at når man kunne slå Kibaki og hans støtter i forfatningsspørgsmålet, måtte man under det samme orange banner kunne gentage kunststykket ved præsidentvalget. Måske troede man det slet ikke, men brugte alligevel argumentationen til at indgyde modstanderne af Kibaki og hans alliance tro på, at det ville være muligt at vinde igen.

Tilsvarende hæftede man sig en del ved de meningsmålinger, der igennem 2007 forudsagde sejr til ODM og Raila Odinga, som endte med at blive oppositionens præsidentkandidat. Man hæftede sig des- værre mindre ved, at afstanden mellem de to ledende kandidater blev mindre efterhånden, som man kom nærmere til valget, dvs. Odingas tilslutning faldt og Kibakis steg. De metodiske problemer med at gennemføre troværdige meningsmålinger i et land som Kenya hæftede man sig heller ikke ved.

Det tredje forhold, der er værd at bemærke i forbindelse med forventningerne til valgets udfald, er, at Odingas retorik var klar: Han stod naturligvis til at vinde, og hvis han ikke vandt, kunne forklaringen kun være, at der var blevet snydt ved opgørelsen af valget (sic!). Det er naturligvis et billigt politiker-kneb, som vel primært bruges, når man ikke er sikker på, om man faktisk vil vinde det kommende valg. Men det er under alle omstændigheder uansvarlig tale, især når det bruges over for en befolkning, der ikke er helt trygge ved en valgkommission, hvor langt de fleste medlemmer er udpeget direkte af den siddende præsident, der oven i købet stillede op igen.

Langt alvorligere var det dog, at en ledende kenyansk demokrati-debattør og valgekspert, Koki Muli, ved flere lejligheder sagde det samme. Det burde have diskvalificeret hende fra at blive medlem af ledelsestriumviratet i den nationale valgobservatørorganisation, KEDOF, som donorernes valgstøtteprogram støttede med et endog meget betydeligt beløb, men sådan spillede klaveret åbenbart ikke. 
Forventningerne til valget kan altså sammenfattes på den måde, at mange gav udtryk for tillid til valgadministrationens evne til at gennemføre et godt og troværdigt valg, mens oppositionen gav udtryk for, at man var sikre på at vinde. Og hvis man ikke vandt, måtte det være fordi, at der havde været snyd med i spillet.

\section{Valg og vold}

Der har ved alle de seneste valg $\mathrm{i}$ Kenya været et vist element af vold, men primært før valget, som en del af den almindelige meningsudveksling mellem stammer og partier. Sådan var det også i 2007, hvor en række episoder førte til drab og lemlæstelse, men primært med udgangspunkt i stammemodsætninger, der igen blev reflekteret i parti- og kandidatmodsætninger. Selv om det var trist, var der ingen, der tog særlig notits af det, for det var jo kun, som det plejede at være.

De fleste iagttagere var tilsyneladende af den opfattelse, at valget den 27. december blev afviklet nogenlunde rimeligt de fleste steder, og at de problemer, der var rundt omkring i kredsene, ikke var flere eller andre, end man nu engang må forvente i et land som Kenya. Imidlertid betød den stemning, der var blevet bygget op før valget, at de, der fylkedes under oppositionens banner, ODM, forventede at vinde, mens præsidentens koalition, med det sent etablerede Party of National Unity, PNU, i spidsen, begyndte at frygte, at det måske kunne gå galt $\mathrm{i}$ sidste øjeblik.

Derfor kom der ekstra stor fokus på optællingen og resultatformidlingen, som foregik på den måde, at der blev talt op på de enkelte valgsteder (i gennemsnit 131 i hver af de 210 parlamentsvalgkredse), hvorefter resultaterne blev bragt til tallying centres i valgkredsene, hvor de blev lagt sammen. På begge niveauer skulle der være fuld åbenhed omkring resultaterne. Valgene til lokalråd og parlament blev afsluttet her, og resultaterne bekendtgjort af kredsens returning officer. Herefter skulle han også sørge for, at resultatet af præsidentvalget i kredsen kom frem til det nationale optællingscenter, som fysisk var placeret i Nairobis velkendte arkitektoniske vartegn, Kenyatta International Cenvention Centre, KICC.

Denne proces gik af flere grunde ikke så nemt, som man kunne have ønsket sig. I nogle kredse tog det et par dage at få alle resultater frem fra de lokale afstemningssteder, ligesom der ikke blandt returning officers var enighed om, hvilket af de tre valg man skulle færdigbehandle først. Her spillede det tilsyneladende en rolle for rækkefølgen, hvor meget pression tilstedeværende, utålmodige og usikre lokalråds- og parlamentskandidater kunne udøve på kredsens returning officer. Konsekvensen var, at det i en del kredse trak 
ud, inden der forelå resultater fra præsidentvalget.

Det var yderst uheldigt, for det bidrog til rygter om, at den tid, der var gået, var blevet brugt til at manipulere med præsidentvalgresultaterne fra nogle af valgkredsene. Desværre ser det ud til, at nogle af de internationale valgobservatører kom til at bidrage til disse rygter, som i sidste ende blev anledningen til den voldsbølge, der kort efter eksploderede.

Den forsinkede færdiggørelse af præsidentvalgresultaterne fra nogle valgkredse fik tilstedeværende observatør-teams til at lægge pres på returning officers for at offentliggøre delresultater fra de pågældende kredse. Det var ikke tilladt - netop for ikke at skabe usikkerhed om, hvad resultaterne var - men i en række tilfælde slap sådanne delresultater altså ud. Når så det endelige resultat forelå på et senere tidspunkt, kunne det jo se ud, som om 'nogen' (sikkert nogen, der arbejdede for ECK i KICC) havde ændret på tallene, hvad der så forståeligt nok førte til påstande om snyd og svindel.

Som om dette ikke var nok, var der heller ikke klare regler internt $\mathrm{i}$ ECK for hvilke procedurer, der skulle følges, hvis det viste sig, at der ude i en kreds var opdaget en fejl i det indsendte og allerede offentliggjorte materiale, hvad der i nogle tilfælde betød, at konstaterede fejl i tallene fra nogle kredse ikke blev rettet.
Hertil skal så yderligere lægges, at ingen for alvor hæftede sig ved, at mange af de resultater, der blev offentliggjort tidligt i forløbet, kom fra befolkningsmæssigt relativt små kredse (som jo alt andet lige også må være hurtigst at tælle op), og dem er der relativt mange af i de dele af Kenya, hvor ODM står stærkest. Det betød, at mediebilledet i begyndelsen var præget af gode resultater for Odinga i præsidentvalget og sejr til ODM-kandidater i parlamentsvalgene, altså præcist, som meningsmålingerne havde forudsagt.

Men efterhånden kom der også tal ind fra de områder, hvor koalitionen bag Kibaki stod stærkt, og billedet begyndte så at ændre sig. Samtidig hæftede oppositionen og valgobservatørerne - herunder EU's valgobservatører - sig naturligvis ved, at de resultater, der blev offentliggjort fra nogle af de valgkredse, hvor de havde været, afveg fra de tal, de selv mente at have indsamlet de pågældende steder. At det havde været delresultater, var åbenbart i de fleste tilfælde ikke blevet opfattet - eller den information var gået tabt under den almindelige forvirring. Det er selvfølgelig også - i hvert fald teoretisk - en mulighed, at lokale observatører bevidst har brugt denne gode chance til at sætte lus i skindpelsen.

Man så også i KICC indberetningsskemaer med klare overstregninger og rettelser, hvad der øgede 
mistanken om snyd og bedrag. Det blev derfor besluttet, at nogle få repræsentanter for PNU og ODM skulle gå de indkomne resultater igennem og komme med en melding. Relativt hurtigt kunne de godkende langt de fleste talsæt fra kredsene, mens en mindre bunke fortsat gav anledning til uenighed.

Så gik fjernsynstransmissionerne fra KICC i sort, og lidt senere holdt Kivuitu et improviseret pressemøde, hvor han offentliggjorde det officielle slutresultat, ifølge hvilket Kibaki havde vundet over Odinga med 4.584.721 stemmer mod 4.352.993. De øvrige kandidater havde alle væsentligt mindre. Og allerede samme aften aflagde Kibaki i al hast og uden sædvanlig pomp og pragt ed som Kenyas præsident for de næste fem år.

Så brød balladen løs for alvor (idet der allerede var uroligheder nogle steder i landet), og en forskrækket og forvirret omverden kunne i den næste måneds tid følge med i, hvordan drabstal, tal på overgreb og tal for mennesker, der flygtede fra hus og hjem, voksede og voksede. De præcise tal kender ingen, men det kan også være lige meget. Det afgørende er, at det valg, som mange troede ville vise, hvor godt det går i Kenya, i stedet blevet en eklatant fiasko for alle: ECK og formand Kivuitu leverede ikke det forventede veladministrerede valg, ODM og Odinga fik ikke fat i præsidentposten, således som de havde talt om, Kibaki og PNU vandt nok, men mange sagde, det var sket ved snyd, dvs. der var sat spørgsmålstegn ved vindernes politiske legitimitet, KEDOF - altså de lokale observatører - brugte måneder på at lave en indholdsmæssigt ret pauver rapport, og udstillede problemerne i det kenyanske civilsamfund - og EU's observatører blev beskyldt for med deres præliminære rapport og dens antydninger om snyd at have kastet benzin på det bål af vold, der flammede op efter valget.

\section{AU og Kofi Annan som mæglere}

I denne situation påtog Den afrikanske Union sig en mæglerrolle, som konkret blev udøvet af Kofi Annan sammen med andre 'eminente afrikanske personligheder', og deres sekretariat i Nairobi understøttede bestræbelserne på at bringe ODM og PNU sammen om en aftale, der kunne føre til, at myrderierne og volden standsede.

Disse forhandlinger foregik - og det er væsentligt - på et tidspunkt, hvor ingen vidste, hvad det 'korrekte' valgresultat var. ODM påstod hårdnakket, at de var blevet regulært snydt, mens PNU i hvert fald sagde, at der ikke var grund til at tvivle på korrektheden af det offentliggjorte resultat. Det var derfor vigtigt, at begge sider accepterede et kompromis. Det bidrog ikke til ODM's kompromisvillighed, at Kibaki havde været endog meget hurtig 
til at fordele alle de centrale ministerposter til de centrale politikere i den koalition af partier (og stammer), der havde støttet hans kandidatur. Betalingen for støtten faldt altså prompte, og det blev igen understreget, at Kenya er et endog meget stærkt præsidentialsystem (hvis nogen skulle have glemt det).

Det nødvendige kompromis blev fundet lidt efter lidt i løbet af slutningen af februar og marts. Det omfattede (1) en hastigt vedtaget forfatningsændring, der sikrede Odinga en ny post som premierminister (men desværre uden at det politiske systems grundlæggende karakter af præsidentialsystem blev ændret), (2) en aftale om ministerposter til mange af Odingas støtter (hvorved regeringen i alt fik mere end $90 \mathrm{mi}-$ nistre og viceministre, som i øvrigt alle skulle findes i parlamentet, som derved fik en anden karakter end forudset i forfatningen), (3) påbegyndelse af et udredningsarbejde omkring en forfatningsreform, der brugte mest muligt af de overvejelser fra arbejdet op til 2005-forslaget, der kunne genbruges, (4) nedsættelse af en undersøgelseskommission, der skulle se på valgets forløb og komme med forslag til tiltag, der ville forhindre en gentagelse, (5) en anden undersøgelseskommission, der skulle analysere volden efter valget og komme med forslag til, hvad man skulle gøre i den anledning, og (6) endelig nedsættelse af en sandheds- og forsoningskommission.
Kommissionen, der skulle se på, hvordan valget var blevet gennemført, blev døbt Independent Review Commission (forkortet IREC), men i daglig tale fik den navn efter sin formand, en højt respekteret sydafrikanske dommer (og tidligere valgkommissionsformand i Sydafrika) ved navn Johann Kriegler, altså Kriegler-kommissionen.

Kommissionen fik syv medlemmer, fire kenyanere (to fra hver side) og tre udlændinge, nemlig ud over Kriegler en tanzaniansk dommer og en argentiner, der tidligere blandt andet har været chef for FN's afdeling for valgassistance. Kommissionen fik tilknyttet et sekretariat, hvis leder blev denne artikels forfatter.

\section{Arbejdet i Kriegler-kommissionen}

Kommissionens kommissorium gik ud på, at man skulle finde ud af, hvordan valget egentlig var blevet afviklet, og hvad der havde været af problemer, og så skulle der på denne baggrund stilles forslag til de administrative, lovgivningsmæssige og andre ændringer, der måtte være behov for.

Derimod skulle kommissionen ikke forsøge at finde ud, hvem der egentlig havde vundet valget. Mange kommentatorer mente, at det havde været en oplagt opgave at pålægge kommissionen, men hvordan skulle man kunne gøre det? At gå tilbage og tælle alt om, var nok teknisk mu- 
ligt, men hvis der var snydt ved stemmeafgivningen (og mon ikke der var det mange steder?), så ville det jo ikke hjælpe noget at tælle op igen. Og hvis der i en stemmeurne var for mange stemmesedler, kunne man så med sikkerhed fastslå, hvad det var for nogle, der ikke skulle være der, og som derfor ikke skulle tælles med?

Hertil kom hensynet til det politiske klima: Hvis Kibakis valg havde medført de voldsomme reaktioner fra Odingas tilhængere m.fl., Kenya havde oplevet i januar og februar, hvad der ville der så ikke kunne ske, hvis kommissionen nogle måneder senere kom og fortalte, at efter dens mening skulle Kibaki træde tilbage som præsident, hans handlinger i embeds medfør miste deres gyldighed, og Odinga indsættes snarest belejligt?

Ingen turde tænke på, hvordan kikuyuerne og andre i Kibakis koalition ville reagere i en sådan situation, så derfor var det eneste fornuftige at tage udgangspunkt i, at de, der var erklæret valgt, var valgt. At der så var indledt retssager i forbindelse med nogle af parlamentsvalgene, ændrer ikke ved dette synspunkt.

Kommissionens første opgave var at finde ud af, hvad der egentlig var foregået op til og under valget. Derfor forsøgte vi at komme i dialog med alle væsentlige aktører (herunder ikke mindst ECK), men det viste sig at være vanskeligt. Et par whistleblowers ville ikke snakke med os eller havde ikke noget at fortælle, der kunne hjælpe.

Civilsamfundet kom heller aldrig med egentlig relevant information, ODM's klageskrift viste sig at være tyndt og byggede helt klart på forskellige misforståelser, de interne vidner fra KICC, vi talte med, kunne alligevel ikke fortælle noget, KEDOF var langtfra færdig med sin rapport (og da den endelig kom, var den ikke særligt givende) - og EU EOM, altså EU's observatørmission kunne eller ville ikke hjælpe med at give adgang til nogle få rapporteringsskemaer, som kommissionen anmodede om at få fortrolig adgang til.

Desuden gav en lang række møder rundt omkring i landet heller ikke noget særligt med hensyn til specifik viden om, hvad der egentlig var foregået, kun et godt indblik i folkestemningen, der primært afspejlede den lokale stammestruktur, således at møderne gav et nyttigt indblik i de etniske og politiske spændinger i landet, men ikke meget mere.

\section{Tre spor}

Kommissionen var altså i betydelig grad på Herrens mark (hvilket var overraskende i betragtning af de mange offentlige udtalelser og protester), og vi måtte derfor selv finde på noget. Tre spor viste sig særligt nyttige:

Registrering af vælgerne er et centralt element i forberedelsen af et 
valg. Selv om man fra ECK's og det donorfinansierede valgstøtteprojekts side havde gjort et vist arbejde $\mathrm{og}$ fået registreret næsten to mio. nye vælgere i løbet af 2007, havde man lukket øjnene for, at man i mange år næsten ikke havde fået renset de døde og de fraflyttede ud af gamle grundregistre og det register, der var blevet brugt i 2005. Det betød, at ca. 1,2 mio. af de 14,3 mio. vælgere på valglisterne ikke skulle være der, enten fordi de var døde, eller fordi de også var registreret på en anden adresse.

Hertil kom, at de 14,3 mio. registrerede vælgere under alle omstændigheder kun udgjorde lidt over 70 pct. af de næsten 20 mio. kenyanere over 18, som har fået udstedt et nationalt ID-kort, og som derfor er den egentlige målgruppe for vælgerregistreringen. Den markante underregistrering ramte som altid især kvinder, unge og visse etniske grupper. Sagt kort: Valglisterne rummede mange navne, der ikke skulle være der, og mange af dem, der burde have været der, var der ikke.

ECK's resultatopgørelser ved valgets afslutning var i en del tilfælde pinligt dårlige. Vi gennemførte som næunt ovenfor ingen kontroller af selve stemmeoptællingen, for det gav ikke mening. Derimod blev overførslen af resultater fra afstemningsstederne til valgkredsniveauet kontrolleret i et antal mere eller mindre tilfældigt udvalgte valgkredse, hvilket førte til identifikationen af en betydelig mængde fejl. I nogle tilfælde var samtlige eller næsten samtlige stemmetal for kandidaterne i såvel præsident- som parlamentsvalget forkerte, somme tider med en del tusinde stemmer, i andre tilfælde kun lidt.

Mange af de officielle resultater havde også tal for 'afgivne, gyldige stemmer', der ikke svarede til summen af kandidaternes stemmetal, igen i nogle tilfælde med en afvigelse på adskillige tusinder. Det var ingen opmærksomme på, før Krieglerkommissionen identificerede denne kilde til forvirring.

Det var vigtigt, idet de mange forskellige tal, der var i omløb, blandt andet førte til meget svingende deltagelsesprocenter ved præsident- og parlamentsvalg i samme valgkreds, noget som ODM og civilsamfundet byggede en betydelig del af kritikken af ECK på. Men med vore mere gennemarbejdede tal var der ikke længere noget særligt at komme efter på dette felt - i hvert fald ikke i de undersøgte kredse.

I begyndelsen af forberedelsesfasen havde ECK haft et konstruktivt samarbejde med den velanskrevne internationale valgstøtteorganisation International Federation for Electoral Systems (IFES). Samarbejdet drejede sig især om rådgivning på it-fronten og udvikling af resultattransmissionssystemer, der dels kunne øge hastigheden i resultattransmissionen fra optællingen på afstemningsstederne til den officielle offentlig- 
gørelse af slutresultater fra KICC, dels kunne mindske sandsynligheden for, at der undervejs i processen blev manipuleret med resultaterne.

Af grunde, som kommissionen aldrig blev i stand til at trænge til bunds i, udviklede samarbejdet sig imidlertid dårligt, og ECK afbrød overraskende samarbejdet på et ret sent tidspunkt. En række uheldige håndteringer af indkøb af unødigt kostbare bærbare computere og printere, dårlig planlægning af træningskurser og inkompetence førte derfor til, at væsentlige dele af resultatindsamlingen og -formidlingen foregik på et lavteknologisk niveau, som bidrog til fejl, langsommelighed og en kritik af ECK, der ikke var spor uberettiget.

\section{Kommissionens konklusion}

Det billede, der herefter tegnede sig for kommissionen, var et, hvor ECK's forberedelse og gennemførelse af de tre valg var præget af en grad af inkompetence og mangel på ansvarlighed, som ingen af de involverede valgeksperter med international erfaring mente at have set mage til andre steder i verden.

Stort set alt, hvad der kunne gå galt, var gået galt, og selv om de fleste risici var blevet fremført veldokumenteret for ECK såvel af IFES og civilsamfundet som af donorerne og deres valgstøtteprojekt, havde man bevidst eller ubevidst - overhørt de mange advarende røster, deriblandt forslagene til at løse problemerne. Hertil kom en række betydelige svagheder i den gældende lovgivning og en uhensigtsmæssig organisatorisk struktur, som yderligere bidrog til fuldstændigt at underminere ECK's almindelige legitimitet og troværdighed.

Den overraskende samlede konklusion blev således en helt anden, end hvad næsten alle havde forventet: I stedet for at finde frem til, hvem der i det nationale resultatcenter havde manipuleret med resultaterne til præsident Kibakis og PNU's fordel - hvilket angiveligt havde fremkaldt den omfattende voldsbølge - kom vi til den konklusion, at ECK havde fungeret ualmindeligt ringe, at der havde været svindel i mindre skala mange steder rundt i landet - og alle steder til den lokalt dominerende stammes (og de dermed forbundne partiers) fordel.

Man kunne altså ikke sige, at der ikke havde været et betydeligt element af svindel og manipulation ved valget - men det havde altså ikke kunnet påvises, at det var sket der, hvor mange mente, at det var sket. De to kommissionsmedlemmer, der var udpeget af ODM, tog i øvrigt forbehold for visse dele af konklusionen, nemlig primært vedrørende de dele, der trak tæppet væk under ODM's og civilsamfundets kritik af opgørelsen af præsidentvalget i KICC.

Et tentativt forsøg på at bedømme 
kvaliteten af administrationen af valget i Kenya ud fra en række indikatorer giver som resultat en score på 54 på en skala fra 0-100. Det er det næstlaveste, der hidtil er registreret $\mathrm{i}$ et projekt, der forsøger at udvikle et sådant måleinstrument (det laveste hidtil var præsidentvalget i zimbabwe i 2002). Den lave score på dette mål underbygger naturligvis Kriegler-kommissionens overordnede konklusion.

Kommissionen skulle ikke bare finde ud af, hvordan valgforberedelserne og valget egentlig var forløbet. Den var også blevet pålagt at komme med forslag til, hvad man kunne gøre for at forhindre en gentagelse. De fremlagte forslag var drastiske: $\mathrm{Al}$ relevant lovgivning burde gennemgås omhyggeligt og revideres, så valglovgivningen kunne leve op vælgernes og partiernes berettigede forventninger, ECK skulle nedlægges i sin nuværende form, og en helt ny organisatorisk struktur etableres for en ny og stærkere valgadministration, der også skulle kunne sikre, at gennemførelsen af valg i Kenya i fremtiden ville kunne leve op til almindeligt anerkendte internationale standarder.

\section{Hvad gik galt?}

Der er mange grunde til at spørge, hvad der gik galt i forbindelse med valget Kenya i december 2007. En grund er hensynet til de mange voldsofre og deres pårørende, en anden, at erkendelsen af at meget af volden var etnisk baseret, gør det nødvendigt for det kenyanske samfund at komme til en form for afklaring med hensyn til, hvorledes de mange stammer skal leve sammen i fremtiden.

Men man er også nødt til at se i øjnene, at hensynet til landets fremtidige udvikling gør det nødvendigt at komme til en form for afklaring med hensyn til, hvad der egentlig skete i tiden efter valget. En sådan afklaring vil kunne bidrage til, at det bliver nemmere at få gennemført de ændringer af forfatningen og af valglovgivningen (og andre former for lovgivning), som nu ligger foran parlament og regering, om end udsigterne til hurtige og overbevisende løsninger forekommer at være beskedne.

Det forekommer mærkeligt, at ingen donorer eller andre iagttagere før valget hæftede sig ved, at ECK egentlig aldrig har været særlig villig til at samarbejde med hverken interne eller eksterne partnere, selv om det ikke har skortet på opfordringer, anbefalinger og pekuniær støtte. Så hvorfor kunne donorerne tro, at man ville kunne samarbejde på en god og konstruktiv måde i 2007?

Hertil kommer, at tidligere valg i Kenya (1992, 1997, 2002) altid har haft en meget solid front runner, hvad der har betydet, at den reelle politiske konkurrence har været beskeden. ECK har derfor aldrig før skullet administrere et valg, hvor 
konkurrencen mellem partier og kandidater var så intensiv - og udfaldet så usikkert - som i 2007. Institutionen manglede altså relevant erfaring, og fordi ECK's medlemmer blev udpeges af præsidenten og ikke ud fra saglige kriterier, manglede kommissionen også såvel kompetence som politiske legitimitet. Og selv den respekterede formand, Kivuitu, manglede erfaring med tætte valg.

Ingen hæftede sig ved, at Odingas forspring i meningsmålingerne blev reduceret frem mod valget, hvilket jo tyder på et tættere og tættere opløb. Hertil kom, at Odinga inden valget havde sagt, at hvis han ikke vandt, kunne forklaringen kun være snyd ved opgørelsen! Synspunktet var i øvrigt før valget blevet bakket op af en af dem, der ledede de lokale valgobservatører. Men disse synspunkter blev på ingen måde nuanceret, selv om Odingas forspring i meningsmålingerne inden valget altså blev mindre og mindre.

Så forklaringen på de store politiske frustrationer, der slog ud i vold efter valget, skyldes altså en sørgelig blanding af dårlig forberedelse og gennemførelse af selv de mest elementære aspekter af valgprocessen, kynisk politisk argumentation om chancerne for bestemte udfald, som ikke byggede på ædruelige analyser af den politiske situation, Kenyas velkendte, traditionelle etniske spændinger, personlige ambitioner, medier uden ansvarsfølelse - og oven i det hele en tradition for poli- tisk (og anden) korruption kombineret med a policy of impunity, dvs. en tradition for, at meget som egentlig er strafbart, på den ene eller den anden måde ender med, at den skyldige ikke i praksis drages til ansvar for sin handling.

\section{Mulige policy-konsekvenser?}

Man sagde tidligere, at ved valg $\mathrm{i}$ Afrika er der sikkerhed om udfaldet, men usikkerhed om, hvordan valget vil blive afviklet administrativt, og hvordan hele valgprocessen vil forløbe. Ved et ordentligt valg bør det derimod være omvendt: Usikkerhed om udfaldet, men sikkerhed om kvaliteten $i$ afviklingen af valget. I Kenya var der valgene i december 2007 usikkerhed om både udfald og afvikling, og det er en ny kombination. Når den indtræffer, kan alt åbenbart ske.

Dette valg - som donorerne gerne havde set som et eksempel på, hvor meget godt der kommer til at ske, når man sætter god regeringsførelse og støtte til frie og fair valg i højsædet - blev altså det stik modsatte, dels på grund af en ufuldstændig analyse af forudsætningerne (ikke mindst den etniske faktors fortsatte betydning), dels fordi man ikke var konsekvent og stringent i kravene til ECK og andre kenyanske samarbejdspartnere.

Det internationale samfund kunne passende bidrage til en styrkelse af fremtidige valg - og dermed den 
almindelige demokratiudvikling $\mathrm{i}$ Kenya - ikke bare med råd og praktisk hjælp til den komplicerede og langsommelige genopretnings- og lovgivningsproces, men også ved at træffe en klar og tydelig beslutning om ikke igen at ville bruge betydelige donormidler på valg, der ikke kan forventes at blive af acceptabel kvalitet. Men nogle donorer er desværre allerede gået $i$ gang med at give støtte til at forberede elementer, der skal føre frem til de kommende valg, tilsyneladende uden at den slags krav er formuleret.

Dermed undermineres de muligheder, det internationale samfund har for at udøve et nødvendigt pres på det politiske system i Kenya. At starte støtten til de næste valg inden ny lovgivning (herunder relevante forfatningsændringer) og en reformeret valgkommission er på plads, er ikke nogen god idé.

Hvis ikke der gennemføres ændringer, der grundlæggende svarer til IREC's anbefalinger, må det forudses, at landets næste valg vil få et lige så trist forløb som det i december 2007. Der er nemlig ingen udsigt til, at intensiteten i den etnisk baserede politiske kamp om præsidentposten vil blive mindre i 2012 , end den var i 2007.

Jørgen Elklit er professor $i$ statskundskab ved Aarhus Universitet. Han var sekretariatsleder ved The Independent Review Commission i Kenya.

Rapporten fra Independent Review Commission kan downloades fra: www.dialoguekenya.org/report.aspx 